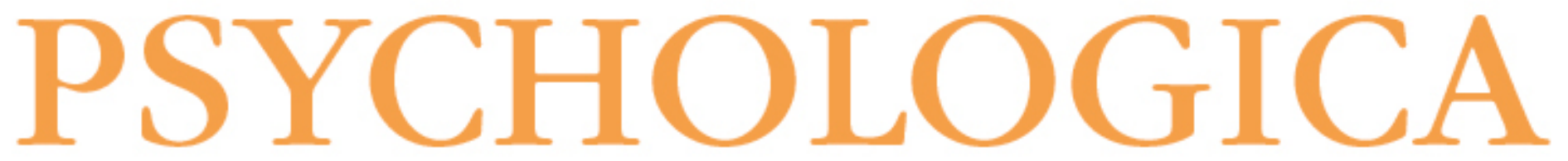

\title{
Development and psychometric study to the Scale of Organizational Sources of Stress on teaching in higher education
}

\author{
Autor(es): $\quad$ Jordão, Filomena; Aragão, Angélica \\ Publicado por: Imprensa da Universidade de Coimbra \\ URL \\ persistente: URI:http://hdl.handle.net/10316.2/29956 \\ DOI: $\quad$ DOI:http://dx.doi.org/10.14195/1647-8606_56_4 \\ Accessed : $\quad$ 26-Apr-2023 14:30:11
}

A navegação consulta e descarregamento dos títulos inseridos nas Bibliotecas Digitais UC Digitalis, UC Pombalina e UC Impactum, pressupõem a aceitação plena e sem reservas dos Termos e Condições de Uso destas Bibliotecas Digitais, disponíveis em https://digitalis.uc.pt/pt-pt/termos.

Conforme exposto nos referidos Termos e Condições de Uso, o descarregamento de títulos de acesso restrito requer uma licença válida de autorização devendo o utilizador aceder ao(s) documento(s) a partir de um endereço de IP da instituição detentora da supramencionada licença.

Ao utilizador é apenas permitido o descarregamento para uso pessoal, pelo que o emprego do(s) título(s) descarregado(s) para outro fim, designadamente comercial, carece de autorização do respetivo autor ou editor da obra.

Na medida em que todas as obras da UC Digitalis se encontram protegidas pelo Código do Direito de Autor e Direitos Conexos e demais legislação aplicável, toda a cópia, parcial ou total, deste documento, nos casos em que é legalmente admitida, deverá conter ou fazer-se acompanhar por este aviso.

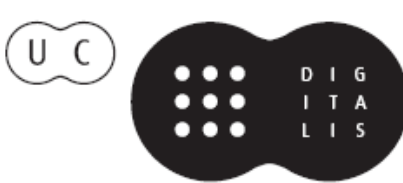


VOLUME 2013

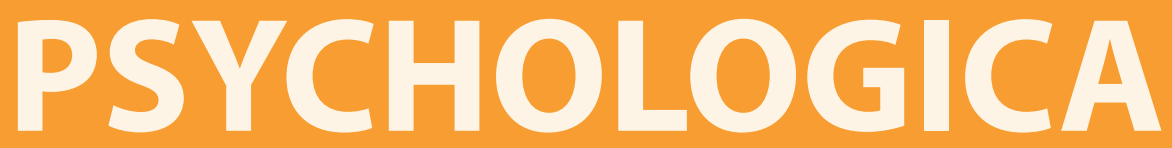

IMPRENSA DA UNIVERSIDADE DE COIMBRA

COIMBRA UNIVERSITY PRESS

FACULDADE DE PSICOLOGIA E DE CIÊNCIAS

DA EDUCAÇÃO DA UNIVERSIDADE DE COIMBRA 


\title{
Development and psychometric study to the Scale of Organizational Sources of Stress on Teaching in Higher Education ${ }^{1}$
}

\author{
Filomena Jordão and Angélica Aragão²
}

\begin{abstract}
Working environments given the great instability and turbulence of modern times, have become more demanding and stressful for most workers. Specifically in higher education teaching context this phenomenon is alarmingly increasing (Winefield, 2000). For this reason, we consider important to acknowledge the potential sources of stress in specific working contexts, given the role that this knowledge might have on the assumption of preventive primary and secondary intervention measures on occupational stress, which are themselves the most efficient ones (Lamontagne, Keegel, Louie, Ostry, \& Landsbergis, 2007).

The purpose of this study is to develop an instrument and carry out a preliminary psychometric study to the Scale of Organizational Sources of Stress on Teaching in Higher Education. We based the development of the scale on literature review and on the results of content analysis of individual interviews to higher education academics. Initially composed by 28 items, the scale was applied to 236 academics of public and private higher education organizations (university and polytechnic) in Oporto.

After the exploratory factor analysis and the internal consistency analysis of the factors extracted, which collectively explain $55,4 \%$ of total variance, the scale was composed by 20 items grouped into four factors: characteristics of the job $(\alpha=.87)$, organizational climate $(\alpha=.85)$, career development $(\alpha=.78)$ e working conditions $(\alpha=.74)$. The final factors structure reveals a discriminating power between the factors, which leads us to
\end{abstract}

1 Part of this work was presented in oral communication VII Simpósio Nacional de Investigação em Psicologia, held in February 2010 in Braga.

2 Filomena Jordão, Centro de Psicologia, Faculdade de Psicologia e de Ciências da Educação, Universidade do Porto; Angélica Aragão, Centro de Psicologia, Faculdade de Psicologia e de Ciências da Educação, Universidade do Porto.

Filomena Jordão currently does not belong to the Center of Psychology; Angélica Aragão does not belong to any of the institutions. E-mail: fjordao@fpce.up.pt 
believe that the scale is able to differentiate the various sources of stress in this type of work contexts. Studies to validate the scale nationwide are now a priority.

Key-words: occupational stress; organizational sources of stress; teaching in higher education; psychometric studies

\section{Desenvolvimento e estudo psicométrico da Escala de Fontes Organizacionais de Stresse na Docência Universitária}

\section{Resumo}

Os ambientes de trabalho, dada a grande instabilidade e turbulência dos tempos modernos, têm-se tornado mais exigentes e stressantes para os que neles trabalham. Concretamente, nos contextos de exercício da docência universitária, este fenómeno tem vindo a aumentar de forma alarmante (Winefield, 2000). Por esta razão, consideramos importante o conhecimento das fontes potencialmente indutoras de stresse em contextos profissionais específicos, dado o papel preponderante que este conhecimento pode ter na assunção de medidas preventivas primárias e secundárias do stresse ocupacional, as medidas mais eficazes (Lamontagne, Keegel, Louie, Ostry, \& Landsbergis, 2007).

Assim, pretendemos com este estudo construir e realizar um estudo psicométrico preliminar à Escala de fontes organizacionais de stresse da docência no Ensino Superior. A escala foi construída com base na revisão da literatura e nos resultados obtidos através da análise de conteúdo efetuada a entrevistas individuais realizadas com este objetivo a docentes do Ensino Superior. Inicialmente composta por 28 itens, a escala foi aplicada a 236 docentes de organizações do Ensino Superior (universitário e politécnico) público e privado do Porto.

Após análise fatorial exploratória e análise da consistência interna dos fatores extraídos, que no seu total explicam $55,4 \%$ da variância total, a escala ficou constituída por 20 itens agrupados em quatro fatores: características do trabalho $(\alpha=.87)$, clima organizacional ( $\alpha$ $=.85)$, carreira profissional $(\alpha=.78)$ e condições de trabalho $(\alpha=.74)$. A estrutura fatorial final revela-nos a existência de um poder discriminante entre os fatores, o que nos leva a crer que a escala tem sensibilidade para diferenciar as várias fontes de stresse deste tipo de contextos laborais. Estudos de validação da escala a nível nacional tornam-se, agora, uma prioridade.

Palavras-chave: Stresse ocupacional; fontes organizacionais de stresse; docência no Ensino Superior; estudos psicométricos 


\section{INTRODUCTION}

Nowadays we often hear references to stress in various contexts assuming that this is a phenomenon present in modern societies, across many life domains, whether it may be in families, school, work or others. As far as working contexts are concerned, work itself has suffered a transformation in the after post-industrial revolution period, which led to significant changes in "work" and in the "worker". On the one hand, labour market is often characterized by economic globalisation, introduction of new technologies, services sector expansion, new management models such as production just-in-time, and so on. On the other hand, workers profile at the present time in Europe corresponds mainly to women and older individuals, with short-term contracts and experiencing an employer-employee relationship different from the one that existed in the industrial period (Cooper, 2000; Kinman \& Jones, 2005; Kompier \& Taris, 2005). Due to this changes, labour contexts become more likely to induce occupational stress, which is harmful to the individual as well as to the organization, as has been widely documented (Antoniou \& Cooper, 2005; Beehr \& Glazer, 2005; Cunha, Rego, Cunha, \& Cabral-Cardoso, 2006; Gillespie, Walsh, Winefields, Dua, \& Stough, 2001; Jex \& Crossley, 2005; Michailidis \& Asimenos, 2002).

Currently, in Portuguese society, we face a massive access to higher education and the government expects, in a near future, to increase the number of students in 50\% (Ferreira, 2008). This political guideline introduces changes within the representations we have on higher education and on the figure of higher education teacher. In fact, higher education teaching is a job with high social interest, although it is also one of the most stressful national public careers (Teodoro, 1994). In the international context research shows that the phenomenon of occupational stress in universities has spread alarmingly (Winefield, 2000). Due to the social interest of empirical research in the area of occupational stress in the context of higher education, it is our objective in this study to develop an instrument and subsequently carry out a preliminary psychometric study to the Scale of Organizational Sources of Stress on teaching in Higher Education. To accomplish this purpose we have defined the following research question: "What are the psychometric characteristics of the Scale of organizational sources of stress in higher education?".

Even though we share the transactional perspective of stress (Lazarus, 1991; Lazarus \& Folkman, 1984) we consider fundamental to acknowledge the organizational sources of occupational stress most commonly referred to in specific labour contexts, in order to intervene, at an organizational level, by restructuring these contexts and eliminating and/or reducing, as far as possible, situations/events that can potentially induce occupational stress. According to this premise, our objective 
is to develop an instrument able to identify the organizational sources of occupational stress in the higher education teaching context.

Many authors have identified the main sources of stress referred to by the academics and the results reveal that there is a certain transnational consistency (Devonport, Biscomb \& Lane, 2008; Doyle \& Hind, 1998; Kinman, Jones, \& Kinman, 2006; Michailidis \& Asimenos, 2002). The most frequent sources of occupational stress on empirical researches are: work overload, long working hours, excessive administrative tasks, temporal constraints, the conditions required for career development, lack of recognition for his work, diversity of roles, management and insufficient participation in organizational decisions, interaction with students, high personal expectations, job insecurity, poor interactions with colleagues, injustices and lack of feedback about the performance (Devonport et al., 2008; Doyle \& Hind, 1998; Gibbons, 1998; Gillespie et al., 2001; Gmelch \& Burns, 1991; Kinman et al., 2006; Michailidis \& Asimenos, 2002; Tytherleigh, Webb, Cooper, \& Ricketts, 2005).

Kinman, Jones and Kinman (2006) have compared results of studies conducted in 1998 and 2004 concerning the stability over the years of working hours, specific stressors and psychological stress levels of academics in the UK The majority of academics and researchers have considered that in the period between the studies their work has become more stressful and their responsibilities, as well as working hours, have increased significantly. Approximately $44 \%$ of the participants considered leaving higher education, which may be explained by the fact that they felt insecurity and stress at work, work overload and long working hours, incompatible roles, poor leadership, increased bureaucracy, few opportunities for promotion, lack of recognition for their work and difficult articulation between work and family.

In another research carried out in Australian universities, Gillespie, Walsh, Winefields, Dua, and Stough (2001) collected data about the experience of occupational stress as far as the sources of stress, consequences and moderator effects are concerned. The identified sources of stress are: insufficient funds and resources, work overload, poor leadership, job insecurity and insufficient recognition and rewards. The moderator factors they found refer to: working environment (social support from colleagues and directorate, recognition and success, high moral and flexible working conditions) and coping strategies (stress management techniques, articulation between the professional and unprofessional domains and well defined role boundaries).

In conclusion, the main organizational sources of occupational stress in higher education teaching may be grouped into different categories, common to most authors and to various professional contexts (Cartwright \& Cooper, 1997; Cooper \& Marshall, 1977; Cunha et al., 2006; Matteson \& Ivancevich, 1987; Ramos, 2001): physical working conditions - comprising, for instance, illumination, noise, space, 
temperature, etc.; job characteristics - such as work overload, long hours, task characteristics; role in the organization - e.g. role ambiguity, role conflict, responsibility; organizational structure and climate - e.g. team work, competition, organizational structure, participation in decision-making process; interpersonal relationships relationships with colleagues, superiors and subordinates; career development - e.g. job insecurity, performance appraisals, opportunities to progression, training; and, lastly, factors extrinsic to the job - e.g. work-family articulation, significant life events. Although this last category does not include organizational factors, the authors are unanimous in considering that it is intimately related with organizational factors so far as the individual/family context and the work context are life domains that interpenetrate (Cartwright \& Cooper, 1997; Cooper \& Marshall, 1977; Cunha et al., 2006; Matteson \& Ivancevich, 1987; Ramos, 2001). This statement is also true for the other categories because they all may have relations among them, that is why occupational stress hardly occurs in response to only one source of stress and most frequently occurs when various sources act together. This categorization is the basis to the design and development of the instrument to evaluate the sources of occupational stress in higher education teaching.

Given the fact that occupational stress in higher education teaching significantly affects the quality of education and investigation, resulting in dissatisfaction and low organizational commitment, which are consequences harmful to colleagues and students (Armour, Caffarella, Fuhrmann, \& Wergin, 1987), we expect that the use of this instrument can serve as a basis for the diagnosis of Portuguese academic reality and for potential interventions in higher education organizations, contributing to a more holistic comprehension of the professional constraints in this specific working context. 


\section{METHOD}

Next we will describe the method used to the development process of the Scale of Organizational Sources of Stress on Teaching in Higher Education and the preliminary psychometric study.

\section{Scale development}

\section{Stage 1: items design}

The 28 initial scale items were drawn from a review of literature on organizational stress factors and content analysis of the interviews made with academics. Therefore, the items were grouped into seven categories of sources of stress usually considered: factors intrinsic to the job (physical working conditions and job characteristics); role in the organization; interpersonal relationships; career development; organizational structure and climate; and, at last, factors extrinsic to the job (Cartwright \& Cooper, 1997; Cooper \& Marshall, 1977; Cunha et al., 2006; Matteson \& Ivancevich, 1987; Ramos, 2001). In order to balance the distribution of items by categories, each one was composed by 4 items that were distributed randomly in the scale.

\section{Stage 2: comprehensibility analysis of the items}

In order to analyse the comprehensibility of the items, we conducted a focus group (with audio recording) with seven academics, selected by convenience, although they represented several scientific domains and professional categories. At the meeting, the questionnaire was distributed to academics and they were asked to, initially, fill it in and, secondly, to comment on the sources of stress considered in the Scale of Organizational Sources of Stress on Teaching in Higher Education (they were instructed to add some other sources of occupational stress if necessary). We analysed the focus group according to an interpretative approach (Jupp \& Norris, 1993) and the results revealed that the categories mentioned by the academics match the ones present in the questionnaire provided, so there was no need to reformulate it. However, almost all of the academics have considered that some of the sources of stress had been considerably enhanced by the changes that the Bologna process has recently introduced in higher education teaching. 
PSYCHOMETRIC STUDY OF THE SCALE

\section{Participants}

It was collected by convenience, a sample of 236 participants from 18 higher education organizations in the Oporto area, 48,7\% were male, 51.3\% female, and the ages ranged between 22 and 66 years $(M=41,68, S D=8,80)$. Participants belonged to the polytechnic system $(n=33)$, the non polytechnic public system $(n=145)$ and to the private system $(n=51)$. The distribution of the academics amongst the different professional categories was: 33,9\% were assistants, 43,6 \% were auxiliary/ adjunct professors, 17,6\% were associate/coordinator professors and 4,8\% were full professors. The participants served in higher education for approximately 15 years $(M=14,62, S D=8,10)$. At last, $36,4 \%$ of the academics cumulatively performed management functions.

\section{Instrument}

The Scale of Organizational Sources of Stress on Teaching in Higher Education consists of two groups of questions. The first group aims to gather participants' personal data: sex, age, professional categories, teaching hours per week, years of teaching in higher education and accumulation of management functions. The second group of questions aims at assess potential sources of occupational stress and consists of 28 items, randomly distributed in the scale, belonging to seven categories: physical working conditions (items 1, 3, 8 and 26); job characteristics (2, 7, 9 and 25); role in the organization (5, 13, 21 and 22); organizational structure and climate (6, 11, 14 and 27); interpersonal relationships (16, 17, 20 and 24); career development (12, 15, 19 and 23); and, factors extrinsic to the job (4, 10, 18 and 28). Items are rated on a Likert scale of six points: $1=$ Almost never a source of stress and $6=$ Almost always a source of stress.

\section{Procedure}

To apply the Scale of Organizational Sources of Stress on Teaching in Higher Education, academics were selected to be responsible for the administration of the questionnaires in their respective organization, in order to facilitate the participation 
of other colleagues in this project. Completed questionnaires were collected and then delivered by the responsible academics to the investigation team.

\section{Data analysis}

The collected data were analyzed with the purpose of ascertaining the validity of the scale and its psychometric quality. In this sense we used exploratory factor analysis (principal components analysis with Varimax rotation) to define the underlying structure of the scale by drawing a number of factors, as well as to summarize and reduce the data (Hair, Anderson, Tatham, \& Black, 2005). To assess the internal consistency of the extracted factors we also calculated Cronbach's alpha values. Subsequently, further analyses were carried out such as comparisons of means by t-Student tests and ANOVA's and correlations between variables by Pearson's correlation coefficient.

\section{RESULTS}

We tested the dimensionality of the instrument through the exploratory factor analysis, principal components method with Varimax rotation. Prior to any factor analysis, the missing values were replaced by the mean of the variable (for all the responses of the 236 subjects at the 28 items of group II, 26 missing values were replaced $-0,4 \%)$. To assess the viability of this statistical test it was used KMO test (Kaiser-Meyer-Olkin Measure of Sampling Adequacy) having been obtained a value of 0,879 , a value considered to be very satisfactory, according to Hair, Anderson, Tatham, and Black (2005) and Bartlett's sphericity test that allowed us to conclude that the correlations matrix is significant $\left(\chi_{(378)}^{2}=2736,436 ; p=0,000\right)$ and so we can assume the factor analysis method as viable.

In a first factor analysis six factors were extracted, which together explained $58,73 \%$ of the total variance. Only factors with eigenvalues superior than one were retained. Since some of the items did not meet the conditions required to be kept, other factor analysis were conducted to eliminate items that did not fulfil the following criteria: a) communalities lower than 0,45 ; b) loadings lower than 0,40 (Stevens, 1986), and c) simultaneous loadings on two factors with a difference between them of less than 0,10 . In this sense, in the continuous process of analysis the following items were removed: 4 - political conjuncture ( = 0,360), 14 - lack of teamwork, 18 - factors of the everyday life and 22 - to meet expectations (all the 
three items had loadings on two factors with a less than 0,10 difference), and 23 job instability $(=0,444)$. Once those items were removed we obtained satisfactory results which enabled us to structure the scale in six factors that altogether explain $64,61 \%$ of the total variance being that: the Factor 1 explains 30,66\%, Factor 2: 11,74\%, Factor 3: 6,93\%, Factor 4: 6,07\%, Factor 5: 4,80\% and Factor 6: 4,41\%. The KMO test $(0,876)$ and Bartlett's test $\left(\chi_{(253)}^{2}=2233,507, p=0,000\right)$ continued to be satisfactory, as the values of communalities. It should be noted that Factor 6 was eliminated since it was constituted only by item 16 - relationship with students. After internal consistency analysis of the five factors considered, by Cronbach's alpha values, only four factors obtained good/satisfactory values because Factor 5 did not reach the lower limit to be considered acceptable $(\alpha=.325)$, according to Hair et al. (2005).

To better understand the Scale factorial structure and the constitution of each factor, in the next table we reveal the loadings on the four components extracted as well as the alpha values for each factor (cf. Table 1). The items were grouped as follows: Factor 1, job characteristics, reflects the individual's relationship with his work; Factor 2, organizational climate, corresponds to perceptions regarding the work environment of which communication processes and interpersonal relationships are inherently included; Factor 3, career development, demonstrates the stressor potential of career opportunities to progression; and finally, Factor 4, working conditions, refers to physical, human and/or materials necessary to professional performance. 
Table 1

Final Factorial Structure and Alpha Values

\begin{tabular}{|c|c|c|c|c|}
\hline & \multicolumn{4}{|c|}{ Components } \\
\hline & 1 & 2 & 3 & 4 \\
\hline Reconciliation of multiple professional roles (5) & .794 & & & \\
\hline Task diversity (25) & .775 & & & \\
\hline Work overload (7) & .772 & & & \\
\hline Nature of the tasks (2) & .698 & & & \\
\hline Working pace I impose myself (9) & 689 & & & \\
\hline Responsibilities inherent to my functions (13) & .654 & & & \\
\hline Work-family articulation (10) & .525 & & & \\
\hline Environment experienced in the organization (11) & & .809 & & \\
\hline Relationship with superiors (20) & & .781 & & \\
\hline Power struggles $(6)$ & & .751 & & \\
\hline Relationships with colleagues (24) & & .742 & & \\
\hline Communication distortions (17) & & .634 & & \\
\hline Performance appraisals (19) & & & .812 & \\
\hline Career progression requirements (12) & & & .678 & \\
\hline Continuous training (15) & & & .666 & \\
\hline Research/teaching dilemma (21) & & & .577 & \\
\hline Lack of adequate material resources (8) & & & & .749 \\
\hline Lack of adequate human resources (26) & & & & .741 \\
\hline The way university is organized (27) & & & & .659 \\
\hline Physical environment (1) & & & & .636 \\
\hline Eigenvalues & 7,05 & 2,70 & 1,59 & 1,39 \\
\hline Variance explained (\%) & 30,66 & 11,74 & 6,93 & 6,07 \\
\hline Cronbach's alpha & .866 & .849 & .784 & .744 \\
\hline
\end{tabular}

\section{DISCUSSION}

We chose to study the psychometric characteristics of the Scale of Organizational Sources of Stress on Teaching in Higher Education in a nomological perspective based on previous theoretical models, trying to acknowledge the factorial structure of the scale in order to understand in what extent the theoretical conceptualizations of the sources of occupational stress (Cartwright \& Cooper, 1997; Cooper \& Marshall, 1977; Cunha et al., 2006; Matteson \& Ivancevich, 1987; Ramos, 2001) are reflected in this instrument. We found that the structure of the scale reflects somehow the most common sources of occupational stress in the empirical studies on the subject of higher education teaching. However, the struc- 
ture originally envisaged during the construction of the Scale of Organizational Sources of Stress on Teaching in Higher Education does not correspond exactly to the factors extracted, which does not invalidate its relevance as a measure of sources of stress in higher education teaching. In fact, there were four factors with very satisfactory internal consistency values for factors 1 and $2(\alpha>.80)$ and satisfactory to factors 3 and 4 with alpha values ranging between 0,70 and 0,80 , therefore we can say that the extracted factors are actually measuring the intended construct (Byrman \& Cramer, 1992). The categories defined a priori as a result of literature review and prior interviews to the academics - physical working conditions, job characteristics, role in the organization, organizational structure and climate, interpersonal relationships, career development and factors extrinsic to the job - do not match directly with the factor structure found. The final factor solution found for the arrangement of the items showed us a frame of reference based on only four factors which we have interpreted as job characteristics, organizational climate, career development and working conditions that altogether explain $64,615 \%$ of the total variance.

The job characteristics factor initially encompassed items divided into the categories job characteristics and role in the organization (in the latter case, items relating to the conciliation of multiple roles and responsibilities inherent to the profession). These overlapping categories may suggest that university teaching is characterized by high quantitative work overload which results in different roles necessarily related to work characteristics. That is, we may assume that academics consider their roles as stressful due to the tasks they have to accomplish and not as a particular dilemma related to the various roles they have to play. Indeed, this factor is mostly composed by items that ultimately demonstrate the work overload that teachers have to face, which is supported by international researches showing that this is a source of stress across different academic contexts (Devonport et al., 2008; Doyle \& Hind, 1998; Kinman et al., 2006; Michailidis \& Asimenos, 2002). Kinman, Jones and Kinman (2006), in their study conducted in the UK, as well as Blix, Cruise, Mitchell, and Blix (1994), confirm that the intention to leave this occupation is due largely to the plethora of sources of stress related to work overload such as long working hours, poor balance between work and family, excessive administrative tasks, among others. This factor also includes the work-family articulation item that was expected to be related to the category of factors extrinsic to the job. Even though we expected a clear distinction between intrinsic and extrinsic factors to the job, in fact academics apparently do not separate the two concepts. In reality, work and family are not completely separate compartments and influence one another, so it makes sense to understand the work-family articulation as management of personal roles that inevitably reflects in job performance (Bellavia \& Frone, 2005; Blix, Cruise, Mitchell, \& Blix, 1994). This can 
be a more important issue for academics than the research/teaching dilemma. The latter, in the extracted factors, appears related with the career development factor so it is perceived more as a condition for career development rather than role management difficulties, and this is why the research/teaching dilemma is not included on the job characteristics factor.

In what concerns the organizational climate factor, it is mostly constituted by items originally grouped under interpersonal relationships category (relationships with colleagues and superiors and distortions in communication) and by two items in the organizational structure and climate category (the environment experienced in the organization and power struggles). These last two items may have been perceived as being associated with communication patterns that necessarily reflect a formal hierarchical structure, very often characterized by more or less formalized communication, where the communication itself acts sometimes as a "weapon" available only to certain organizational elements, which demonstrates the relationship between power and communication. The results concerning the perception of organizational climate may also be explained due to schools organizational structure that may allow academics to have autonomy in their functions. Dalmaz and Castro (2008) in their research focused on the evaluation of organizational climate in universities found that communication and interpersonal relationships are intrinsic components of the organizational climate and they also present results suggesting that communication is one of the factors that contributes to less satisfaction in teachers, possibly due to the complexity of the administrative structure of the university. We have chosen to designate this factor as organizational climate because it essentially reflects the subjective perceptions regarding the general environment experienced in the organization, and the communication processes are one of the inherent dimensions of some instruments to assess organizational climate (Dalmaz \& Castro, 2008).

The career development factor was the most related to the previously defined category although it integrated item 21 , research/teaching dilemma, which was initially deemed to be related to the role in the organization category. This factor reflects the stress-inducing potential of career development requirements and, in this sense, we can infer that the research/teaching dilemma exists for the academics as being more focused towards career development (which is mostly done by academic examination, empirical research and publication) rather than as an issue associated with roles and professional identity. Generally, career progression has been considered in some studies as having a high stressor potential (Kinman et al. 2006; Michailidis \& Asimenos, 2002). Gálan Gonzaléz (2007) reveals that teaching is often neglected in favour to research, as a consequence of university policies in the last decades, thus academics may reveal this response pattern 
since they consider this item as a clear reference to the centrality of research as a requirement to career development. We must mention that this research/teaching conflict is included in the career development factor as the second item with the highest mean score $(M=3,92, S D=1,42)$, surpassed only by the item requirements to career progression $(M=3,97, S D=1,49)$ which may indicate that the centrality of research is essential for career development but it is not in itself a conflict but an essential condition to be fulfilled.

The working conditions factor incorporates the initial items of the category (except item 3 which was eliminated since it loaded a factor with low internal consistency) and, interestingly, also includes the item 27 related to the way the university is organized. This item originally present in the organizational structure and climate category may have been understood as an element of organization layout of the institution and in this case it is relevant to be included in this factor which refers to the effects of physical, human and/or materials resources as occupational stress enhancers in higher education teaching. As McCoy and Evans (2005) state, working conditions have a high stressor potential though individuals are often unaware of its effects in their well-being, which justifies its presence in the scale as a factor to be retained $(\alpha=.74)$ and to be reformulated in a future revision of the scale in order to balance the items since it now consists of only four items. Although it is more common in blue-collar contexts (Matteson \& Ivancevich, 1987), this type of physical and/or material stressors also represents a factor to analyze in higher education teaching. To interpret the results of this factor we must take into account the different contexts of origin of the academics, since the social context in which the organization is inserted may enhance or hinder working conditions (Phillips, 1993). This is the case of the private education system that might have an advantage in terms of greater autonomy in managing its own schools. That is, it may be that these organizations have greater opportunity to invest in their human and physical resources, trying to meet the basic working conditions to improve quality of work life.

In summary, the results obtained from the exploratory factor analysis enabled us to state that the organizational sources of stress perceived by academics can be grouped in a similar way (but not exact) to the categories defined a priori to the construction of the scale. The factorial structure found, though not coincident with the model set, reveals the existence of a discriminating power among the factors which lead us to believe that the Scale of Organizational Sources of Stress on Teaching in Higher Education is sensitive to differentiate between various sources of stress in this context of work.

Based on these results we can assume that the Scale of Organizational Sources of Stress on Teaching in Higher Education for this sample, can be considered valid which allows its use for future research on the topic. In future researches, in order 
to an integrative comprehension of the phenomenon of occupational stress in higher education teaching it is important, and under the guidance of transactional models of stress, to combine other scales to assess the cognitive evaluation mechanisms and coping mechanisms underlying a stress event (Cooper, Dewe, \& O’Driscoll, 2001). In reformulations of the Scale it would be interesting to suggest other items that could integrate factors 2, 3 and 4 to ensure greater balance between the factors since the first is constituted by seven items, the second by five and the other by only four. Moreover, it would also be important to monitor whether the teaching activity is exercised in one or more contexts of higher education, recurrent situation in these contexts, and that can influence the perception of occupational stress factors but by methodological contingencies, was not controlled in our study.

\section{REFERENCES}

Antoniou, A-S., \& Cooper, C. (2005). Preface. In A-S. Antoniou, \& C. Cooper (Eds.). Research companion to organizational health psychology (pp. xvi-xvii). Great Britain: Edward Elgar Publishing.

Armour, R. A., Caffarella, R. S., Fuhrmann, B. S., \& Wergin, J. F. (1987). Academic burnout: Faculty responsibility and institutional climate. New Directions for Teaching and Learning, 1987(29), 3-11.

Beehr, T., \& Glazer, S. (2005). Organizational role stress. In J. Barling, E. Kelloway, \& M. Frone (Eds.). Handbook of work stress (pp. 7-33). USA: Sage Publications.

Bellavia, G., \& Frone, M. (2005). Work-family conflict. In J. Barling, E. Kelloway, \& M. Frone (Eds.). Handbook of work stress (pp. 113-147). USA: Sage Publications.

Blix, A., Cruise, R., Mitchell, B., \& Blix, G. (1994). Occupational stress among university teachers. Educational research, 36(2), 157-169.

Byrman, A., \& Cramer, D. (1992). Análise de dados em ciências sociais: introdução às técnicas utilizando o SPSS. Oeiras: Celta Editora.

Cartwright, S., \& Cooper, C. (1997). Managing workplace stress. USA: Sage Publications.

Cooper, C. (2000). Theories of organizational stress. USA: Oxford University Press.

Cooper, C., Dewe, P., \& O'Driscoll, M. (2001). Organizational stress - a review and critique of theory, research and applications. USA: Sage Publications.

Cooper, C., \& Marshall, J. (1977). Understanding executive stress. New York: PBI.

Cunha, M., Rego, A., Cunha, R., \& Cabral-Cardoso, C. (2006). Manual de comportamento organizacional e gestão (5a ed.). Lisboa: Editora RH.

Dalmaz, T., \& Castro, M. (2008). Avaliação do clima organizacional em uma universidade pública. Lato Senso (6 $6^{\mathrm{a}}$ ed.). Paraná: Unicentro. Consultado em

http://web03.unicentro.br/especializacao/Revista_Pos/P\%C3\%A1ginas/6\%20Edi\%C3\%A7\%C3\%A3o/ Aplicadas/PDF/8-Ed6_CS-AvaCl.pdf

Devonport, T., Biscomb, K., \& Lane, A. (2008). Sources of stress and the use of anticipatory, preventative and proactive coping strategies by higher education lecturers. Journal of Hospitality, Leisure, Sport \& Tourism Education, 7(1), 70-81. 
Doyle, C., \& Hind, P. (1998). Occupational stress, burnout and job status in female academics. Gender, work \& organization, 5(2), 67-82.

Ferreira, L. (2008). Recursos humanos e materiais. In Conselho Nacional da Educação. Políticas de Ensino Superior: quatro temas em debate. Lisboa: Editorial do Ministério da Educação.

Galán González, A. (2007). El perfil del profesor universitario. Situación actual y retos de futuro. Madrid: Ediciones Encuentro.

Gibbons, C. (1998). An investigation into the effects of organizational change on occupational stress in further education lecturers. Journal of further and higher education, 22(3), 315-328.

Gillespie, N., Walsh, M., Winefields, A., Dua, J., \& Stough, C. (2001). Occupational stress in universities: staff perceptions of causes, consequences and moderators of stress. Work \& stress, 15(1), 53-72.

Gmelch, W., \& Burns, J. (1991). Sources of stress for academic department chairs: a national study. Association for the Study of Higher Education Annual Meeting Paper.

Hair, J., Anderson, R., Tatham, R., \& Black, W. (2005). Análise multivariada de dados. São Paulo: Bookman. Jex, S., \& Crossley, C. (2005). Organizational consequences. In J. Barling, E. Kelloway, \& M. Frone (Eds.). Handbook of work stress (pp. 575-600). USA: Sage Publications.

Jupp, V., \& Norris, C. (1993). Traditions in Documentary Analysis. In M. Hammersley (Ed.). Social Research: Philosophy, Politics and Practice (pp. 37-51). London: Sage.

Kinman, G., \& Jones, F. (2005). Lay representations of workplace stress: what do people really mean when they say they are stressed? Work \& Stress, 19(2), 101-20.

Kinman, G., Jones, F., \& Kinman, R. (2006). The well-being of the UK academy, 1998-2004. Quality in Higher Education, 12(1), 15-27.

Kompier, M., \& Taris, T. (2005). Psychosocial risk factors and work-related stress. State of the art and issues for future research. In A. Antoniou, \& C. Cooper (Eds.). Research Companion to Organizational Health Psychology (pp. 59-69). Great Britain: Edward Elgar Publishing.

Lamontagne, A., Keegel, T., Louie, A., Ostry, A., \& Landsbergis, P. (2007). A Systematic Review of the Job-stress Intervention Evaluation Literature, 1990-2005. International Journal of Occupational and Environmental Health. 13(3), 268-280.

Lazarus, R.S. (1991). Emotion and adaptation. New York: Oxford University Press.

Lazarus, R.S., \& Folkman, S. (1984). Stress, appraisal and coping. New York: Springer Publishing Company.

Matteson, M., \& Ivancevich, J. (1987). Controlling work stress - effective human resource and management strategies (pp. 33-52). USA: Jossey-Bass Publishers.

McCoy, J., \& Evans, G. (2005). Physical work environment. In J. Barling, E. Kelloway, \& M. Frone (Eds.). Handbook of work stress (pp. 219-246). USA: Sage Publications.

Michailidis, M., \& Asimenos, A. (2002). Occupational stress as it relates to higher education, individuals and organizations. Work, 19(2), 137-147.

Phillips, B. N. (1993). Educational and Psychology perspectives on stress in students, teachers and parents. Vermont: Clinical Psychology Publishing Company.

Ramos, M. (2001). Desafiar o desafio - prevenção do stress no trabalho. Lisboa: RH Editora.

Stevens, J. (1986). Applied multivariate statistics for the social sciences. New Jersey: Lawrence Erlbaum. Teodoro, A. (1994). A carreira docente - formação - avaliação - progressão. Lisboa: Texto Editora.

Tytherleigh, M., Webb C., Cooper, C., \& Ricketts, C. (2005). Occupational stress in UK higher education institutions: a comparative study of all staff categories. Higher education research and development, 24(1), 41-61.

Winefield, A. H. (2000). Stress in academe. Some recent research findings. In D. Kenny, J. Carlson, F. McGuigan, \& J. Sheppard, (Eds.). Stress and Health: Research and Clinical Applications (pp. 437-446). Amsterdam, Netherlands: Harwood Academic Publishers. 